\title{
Perceived Usefulness and Ease of Use of Social Media among Pre-service Teachers in Ghana
}

\author{
Daniel Paa Korsah'1, Issah Bala Abdulai², Daniel Gbormittah ${ }^{1}$ \\ ${ }^{1}$ Komenda College Education - Ghana, ${ }^{2}$ Kibi Presbyterian College Education - Ghana
}

\begin{abstract}
The study examined the level of Perceived Usefulness (PU) and Perceived Ease of Use (PEOU) of social media within the framework of the Technology Acceptance Model (TAM) in order to ascertain the usefulness of social media among Pre-service Teachers in Ghana. Stratified random sampling was used to select 391 Pre-service Teachers for the study. Data was collected using a questionnaire and analysed based on descriptive statistics and an Independent sample t-test. This study found that majority of the Preservice Teachers use two social media platforms; WhatsApp and Facebook. The study further established a significant difference between Pre-service Teachers whose usage of social media sites specifically affect their perceived usefulness and those that specifically affect their perceived ease of use. The study encouraged teachers to integrate e-learning applications like Blackboard, Google Classroom and Edmodo in their courses (using the blended learning approach) as they have social media-like features that students have already embraced. This study contributed to research on the possibility of integrating social media into teaching and learning in Colleges of Education in Ghana.
\end{abstract}

Keywords: Pre-service Teachers, social media, perceived usefulness, perceived ease of use, Technology Acceptance Model (TAM).

(C) 2020 The Authors. Published and Maintained by Noyam Publishers.

This is an open access article under the CCBY license (http://creativecommons.org/licenses/by/4.0/).

\section{INTRODUCTION}

The use of social media has gained prominence globally. The advent of social media platforms such as Facebook, WhatsApp, Twitter, YouTube, Instagram and a host of others, have made users worldwide more connected to each other now than before. The widespread use of the internet and the introduction of online blogging have contributed to the growth of social media. In several respects, social media differs from conventional media in terms of content, scale, length, accessibility, promptness and longevity. ${ }^{2}$ Communication is the fundamental function of a social media system. ${ }^{3}$

Although there is a difference in terms of the speed and intensity of internet, the use of social media for communication is gaining prominence around the world. This is because of their viral nature and how they enable users share new content received or sent in a form of message distribution as soon as possible. ${ }^{4}$ Today's social media has helped to make the concept of a "global village" possible, which was first put forward in the 1960s by communications theorist Marshall McLuhan, and indicated that the arguments of twenty-first-century essayist Thomas L. Friedman about a "flat planet" are valid. Personal computers and the speed of the optical cable in information processing have marked the digital revolution, virtually eliminating time and space constraints. The exponential development of social media as an important way of influencing humanity is part of advancing ICT. ${ }^{5}$

The rapid development of mobile technology and various mobile terminals was critical for social media creation

\footnotetext{
2 Eugene Agichtein, Carlos Castillo, Debora Donato, Aristides Gionis, and Gilad Mishne, "Finding High-quality content in social media," In WSDM '08: Proceedings of the international conference on Web search and web data mining, (2008):183-194.

3 Jan H. Kietzmann, Kristopher Hermken, Ian P. McCarthy \& Bruno S. Silvestre, "Social media? Get serious! Understanding the functional building blocks of social media," Business Horizons 54, 3(2011): 241-251

Andreas M. Kaplan., \& Heinlein Michael, “Users of the world, unite! The challenges and Opportunities of social media," Business Horizons 53, no. 1 (2010): 59-68.

Thomas Friedman, “The World Is Flat 3.0: A Brief History of the Twenty-first Century," Picador (2007).
} 
and use and it is part of the entire operation, which consists of internet communications and online interaction. ${ }^{6}$ Social media is an interactive form of media, which allows users to send multimedia message (text, picture, audio and video) to each other on the internet. ${ }^{7}$ It offers people the opportunity to exchange thoughts, insights, experiences and perspectives in a two-way communication environment. In addition to the sharing of ideas and skills, it also enables immediate and uninterrupted user feedback and responses. ${ }^{8}$

Social media is an internet application category focused on Web 2.0's theoretical and technical basis, enabling user-generated content to be created and shared. Web 2.0 is the second generation of the World Wide Web, which facilitates social networking, media and knowledge exchange. ${ }^{9}$ Invented in 2005 by Tim O'Reilly, the word "Web 2.0" is simply a name for the advancement of Internet-based communications, and it demonstrates that networking and online connectivity have progressed to the next level. Web 1.0, in contrast, refers to the first stage of the World Wide Web's evolution that mainly dealt with static pages. The differences that exist between web 1.0 and web 2.0 technologies consist of: "a move from personal websites to blogs and blog site aggregation, from publishing to participation, from web content as the outcome of large up-front investment to an ongoing and interactive process, and from content management systems to links based on "tagging" website content using keywords." 10

Social media usage is widespread among tertiary students in Ghana. Some research in Ghana has indicated negative effect of social media on the academic performance of tertiary students. ${ }^{11}$ However, there is a scarcity of studies conducted on the usefulness and ease of use of social media among pre-service teachers in Ghana.

This research sought to find the extent to which Pre-service Teachers use social media sites. It further examines the Perceived Usefulness (PU) and the Perceived Ease of Use (PEOU) of social media among Pre-service Teachers within the Technology Acceptance Model (TAM) framework.

The hypothesis that guided the study were as follows:

$\boldsymbol{H}_{\boldsymbol{0}}$ : There is no significant difference between Pre-service Teachers whose usage of social media sites were influenced by their perceived usefulness and those whose usage were influenced by their ease of use.

$\boldsymbol{H}_{\boldsymbol{i}}$ : There is a significant difference between Pre-service Teachers whose usage of social media sites were influenced by their perceived usefulness and those whose usage were influenced by their ease of use.

\section{THEORETICAL FRAMEWORK}

The Technology Acceptance Model (TAM) clarifies and forecasts users' readiness to adopt or accept computer technology. ${ }^{12}$ The concept of TAM is based on Theory of Reasoned Action (TRA), which stipulates Perceived Usefulness and Perceived Ease of Use as determinants of Attitude towards Use, Behavioral Intentions and Actual Usage behaviour of users of IT systems. In the TAM, the desire to use contributes to actual usage and this behavioral intention is mutually determined by attitude and perceived usefulness. Whereas perceived usefulness specifically affects attitude, perceived ease of use affects both attitude and perceived usefulness. Perceived Usefulness is defined as "the degree to which a person believes that using a program will enhance his job performance, while perceived ease of use is defined as the degree to which a person believes that using a program will require less effort". ${ }^{13}$

TAM can be considered as one of the leading model and is commonly used in a variety of information systems adoption reports, primarily due to its all-round implementation and simplicity. ${ }^{14}$ TAM is appropriate in explaining attitudes towards the use of Information Systems. It can be used to predict the intention of use of an Information System, easier to use and more reliable to apply as compared to other models. ${ }^{15}$

\footnotetext{
Ari-Matti Auvinen, n.d., "Social Media - The New Power of Political Influence," Accessed Augus 4, 2016. http://www.martenscentre.eu/sites/default/files/ publication-files/social-media-and-politics-power-political-influence.pdf.

Mac-Jordan,D.Degadjor, “Social Media and Internet Use in Ghana,” (2010),Accessed March 1, 2017. https://www.slideshare.net/macjordangh/social-mediainternet-use-in-ghana

Kaplan \& Michael, "Users of the world, unite! The challenges and opportunities of social media," 67.

9 Davis W. Wilson, Xiaolin Lin, Pjil Longstreet, \& Saonee Sarker, "Web 2.0: A definition, literature review, and directions for future research," AMCIS 2011 Proceedings of the Seventeenth Americas Conference on Information systems, Detroit, Michigan August 4- 7, 2011.

10 Tim O’Reilly, "What Is Web 2.0: Design Patterns and Business Models for the Next Generation of Software," (September 30, 2005 ), Accessed January 6, 2019. http://www.oreilly.com/pub/a/web2/archive/what-is-web-20.html.

11 Damasus Tuurosong \& Mohammed Amadu, (2014). "The Social Media Scourge among University Students: A Study of the University for Development Studies, Ghana”. J. Asian Dev. Stud, 3, no 2, (2014): 62-74

12 Oluwole Durodolu, "Technology Acceptance Model as a predictor of using information system' to acquire information literacy skills," Library Philosophy and Practice, (2016):1450.

13 Waleed Al-Ghaith, "Applying the Technology Acceptance Model to Understand Social Networking Sites (SNS) Usage: Impact of Perceived Social Capita,l” International Journal of Computer Science and Information Technology 7, no. 4 (2015): 105-117.

14 Wynne Chin, W., Johnson Norman, and Andrew Schwarz, "A Fast Form Approach to Measuring Technology Acceptance and Other Constructs," MIS Quarterly 32, no. 4 (2008):687-703. Accessed June 27, 2020. DOI:10.2307/25148867.

15 Kurniabudi Kurniabudi, Sharipuddin \& Setiawan Assegaff, “A Literature Review: Acceptance Models or e-learning Implementation in Higher Institution," International Conference on Advances in Education Technology (ICAET-14), (2015):86-89
} 
The disadvantage of TAM is that it supplies very general information about ease of use and usefulness. ${ }^{16}$ While TAM's parsimony is seen as a power, it can be regarded as a TAM constraint in its two original structures; perceived usefulness and perceived ease of use. It can offer some predictive data but it cannot fully help designers predict acceptance for a new system. ${ }^{17}$ The exclusion of social variables from TAM has drawn criticism from researchers, they lament that many theoretical structures deemed essential in predicting adoption of the technology are overlooked and omitted; ${ }^{18}$ specific personal traits that can have an effect on TAM estimates significantly; ${ }^{19}$ and affect the relationship between the TAM constructs. ${ }^{20}$

The Technology Acceptance Model is largely popular for understanding human technology relationships. The reasons why TAMs were introduced into this research was to evaluate the perceived usefulness and perceived ease-ofuse (PEOU) of social media among Pre-service Teachers. The technology acceptance model constructs are shown in figure 1.

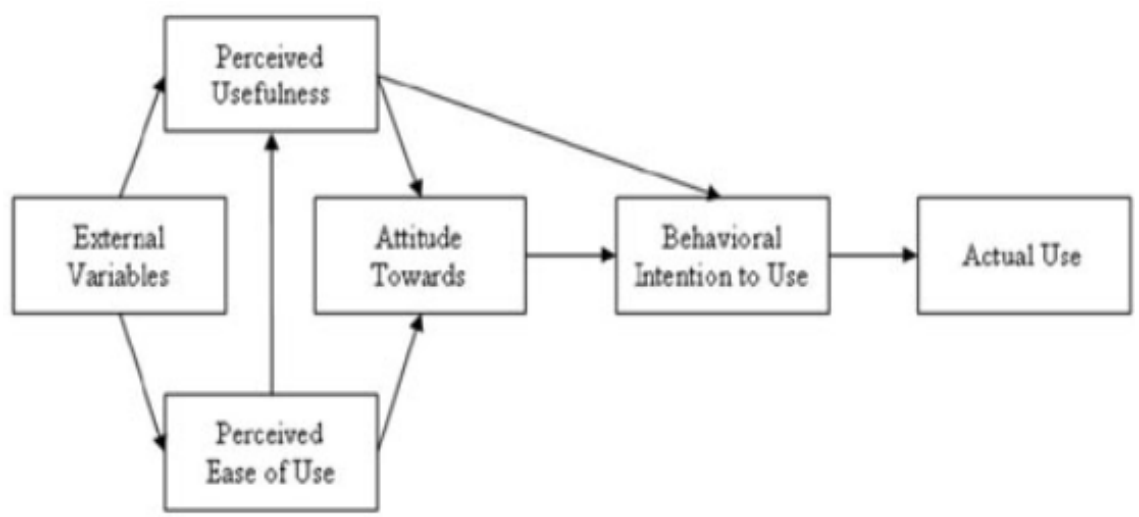

Figure 1: The Technology Acceptance Model

\section{SOCIAL MEDIA AND LEARNING}

Educational institutions across the world are leveraging on the potential of social media technologies to enhance the overall teaching-learning process. Some of these institutions keep social media handles to announce their presence in the social media space. The use of Social media sites for teaching and learning is also gaining grounds among many teachers and students around the globe. Social media do not only provide learners access to useful information but also connect them with learning groups that improve their learning process and makes it more interesting and engaging.

Students collaborate with others to share lecture notes, research on topics and do assignments. ${ }^{21}$ While some students find useful ways to use social media, others use it for negative things. Some teachers have also resorted to the use of social media to supplement classroom teaching and learning. Teachers, therefore, use social media platforms like Pinterest, Facebook, Twitter, YouTube, LinkedIn, Second Life, WhatsApp, Zoom, and Skype in emergency remote situations to support teaching and learning. ${ }^{22}$ Some researchers found that Facebook and WhatsApp are the most frequently used social media by some tertiary students in Ghana, followed by Twitter, Skype and YouTube. ${ }^{23}$ Other studies shows that social media platforms are widely used in tertiary institutions for the academic, professional, and personal benefits. ${ }^{24}$ There are also literatures that points to the fact that when Social media platforms are applied in teaching and learning, it has a positive impact on its usage in teaching and learning and would play key roles in future

\footnotetext{
16 Viswanath Venkatesh, "Determinants of Perceived Ease of Use: Integrating Control, Intrinsic Motivation, and Emotion into the Technology Acceptance Model," Information Systems Research 11, no, 4 (2000): 342-365.

17 Ibid.

18 L. Chen, L.M. Gillenson, \& L.D. Sherrell, “Consumer acceptance of virtual stores: a theoretical model and critical success factors for virtual stores," ACM SIGMIS Database, 35, no. 2 (2004): 8-31.

19 Soussan Djamasbi Diane M, Strong Mark Dishaw "Affect and acceptance: Examining the effects of positive mood on the technology acceptance model," Decision Support Systems 48, (2010):383-394.

20 S. McCoy, D. Galletta \& W. King, W. “Applying TAM across cultures: the need for caution,” European Journal of Information Systems 16 (2007): 81-90.

21 Tay Elaine, \& Allen, Matthew. "Designing social media into university learning: technology of collaboration or collaboration for technology?” Educational Media International, 48, no 3, (2011):151-163

22 Rita Kop \& Adrian Hill, “Connectivism: Learning theory of the future or vestige of the past?” International Review of Research In Open And Distance Learning, 9, no 3, (2008): 1-13

23 Tuurosong \& Amadu, "The Social Media Scourge among University Students: A Study of the University for Development Studies, Ghana."

24 Nikola Draskovic, Martina Caic, \& Ana Kustrak, "Croatian perspective(s) on the lecturer student interaction through social media," International Journal of Management Cases, 15, no 4, (2013):331-339.
} 
of education. ${ }^{25}$ Others reveal that it has negative effect on the academic performance of students ${ }^{26}$ Pre-service Teachers are keen users of social media for socialising and making new friends, but majority of them do not see the usefulness of social media in teaching and learning. ${ }^{27}$

In Ghana Pre-service Teachers are categorized as of tertiary students. They are College of Education students who are undergoing training to become teachers to teach at the basic level of education. Currently the Colleges of Education in Ghana run a Bachelor of Education degree programmes in Early Childhood Education, Primary Education and Junior High School Education. The Pre-service Teachers' perceptions about the usefulness and the ease of use of social media will affect how they accept its use for teaching and learning purposes either positively or negatively.

\section{METHODOLOGY}

The study was a quantitative research that employed descriptive statistics and an independent t-test to analyse the data collected. The study objective 1 to 3 were answered using descriptive statistics. An independent sample t-test was computed to test the hypothesis. The instrument selected for the study was questionnaire. It was used to gather data on the extent to which College of Education students use social media within the context of the Technology Acceptance Model. Respondents answered questions about their use of social media and how many social media services they actively use. Participants further responded on how often they visit social media and how much time they spend on those platforms in a day. They also responded to questions about the perception regarding the usefulness and the ease of use of social media. The items in the questionnaire were closed ended. The data was collected within a period of four (4) weeks

The population for the study comprised the entire student body of Colleges of Education in the Central, Western and Western North Regions of Ghana. Data was drawn from second-year students from the 7 Colleges of Education in these regions. They included Komenda College of Education (Central Region), OLA College of Education (Central Region), Fosu College of Education (Central Region), Holy Child College of Education (Western Region) and Enchi College of Education (Western Region), Wiawso College of Education and Bia Lamplighter College of Education (Western North Region).

Stratified random sampling was used to select 400 students for the study. The strata were as follows: General Students (students offering General programme), Math-Technical students, Science-Maths students and ScienceTechnical students. With the help of the random number generator, 100 students were drawn from each stratum. In all, 400 students were sampled for the study. However, 391 students responded to the questionnaire since 9 students could not participate in the study. The students were made up of 197 males and 194 females.

\section{RESULTS}

This part analyzes the extent of social media usage among students of Colleges of Education in Ghana. The result is displayed in Table 1 to Table 5.

Table 1: Students' Use of Social Media

\begin{tabular}{|l|l|l|}
\hline Use of Social Media & Frequency & \% \\
\hline Yes & 389 & 99.49 \\
\hline No & 2 & 0.51 \\
\hline Total & $\mathbf{3 9 1}$ & $\mathbf{1 0 0 . 0 0}$ \\
\hline
\end{tabular}

Table 1 illustrates the number of students in the Colleges of Education who use social media. It could be seen that $99.49 \%$ of the students answered "Yes" to this question while $0.51 \%$ answered "No", indicating that the majority of college students use social media.

Table 2: Number of Social Media Sites that Students Actively Use

\begin{tabular}{|l|l|l|}
\hline Social Network Site & Frequency & \% \\
\hline One & 24 & 6.14 \\
\hline Two & 117 & 29.92 \\
\hline
\end{tabular}

\footnotetext{
Berhane Teclehaimanot, \& Hickman Torey, “Student-Teacher Interaction on Facebook: What Students Find Appropriate," TechTrends, 55 (2011): 19-30.

26 Tuurosong \& Amadu, "The Social Media Scourge among University Students: A Study of the University for Development Studies, Ghana."

27 U.I. Ogbonnaya, A. Mji, “Pre-Service Teachers”, Use Of Social Media,” Edulearn 15 Proceedings, (2015):1506-1512.
} 


\begin{tabular}{|l|l|l|}
\hline Three & 112 & 28.65 \\
\hline Four & 72 & 18.41 \\
\hline Five & 29 & 7.42 \\
\hline More than Five & 37 & 9.46 \\
\hline Total & $\mathbf{3 9 1}$ & $\mathbf{1 0 0 . 0 0}$ \\
\hline
\end{tabular}

From Table 2, it could be seen that most respondents (29.92\%) are active members of two social media platforms. $28.65 \%$ of respondents are active members of three social network sites. Only 37, representing $9.46 \%$ are active members of more than five social media sites.

Table 3: Social Media Sites that Respondents Use

\begin{tabular}{|l|l|l|l|}
\hline \multirow{2}{*}{ Social Network Site } & \multicolumn{2}{|c|}{ N (\%) } & \multirow{2}{*}{ Total N (\%) } \\
\cline { 2 - 3 } & Those who use it & Those who do not use it & \\
\hline Facebook & $330(84.40)$ & $61(15.60)$ & $\mathbf{3 9 1}(\mathbf{1 0 0 . 0 0 )}$ \\
\hline WhatsApp & $376(96.16)$ & $15(3.84)$ & $\mathbf{3 9 1}(\mathbf{1 0 0 . 0 0 )}$ \\
\hline Twitter & $93(23.79$ & $298(76.21)$ & $\mathbf{3 9 1}(\mathbf{1 0 0 . 0 0 )}$ \\
\hline Instagram & $140(35.81)$ & $251(64.19)$ & $\mathbf{3 9 1}(\mathbf{1 0 0 . 0 0 )}$ \\
\hline YouTube & $224(57.29)$ & $167(42.71)$ & $\mathbf{3 9 1}(\mathbf{1 0 0 . 0 0})$ \\
\hline Others & $39(9.97)$ & $352(90.03)$ & $\mathbf{3 9 1}(\mathbf{1 0 0 . 0 0})$ \\
\hline
\end{tabular}

Table 3 shows that the majority of the students use WhatsApp (96.16\%), followed by Facebook (84.40\%). Twitter (23.79\%) and Instagram (35.81\%) also have some level of usage among students. Other less known social media services such as Imo, Tango, and Viber had just 9.97\%.

Table 4: How often respondents use Social Media sites

\begin{tabular}{|l|l|l|}
\hline Social Network Site & Frequency & \% \\
\hline Daily & 286 & 73.15 \\
\hline Once in every 2-3 days & 57 & 14.58 \\
\hline Once in every 4-5 days & 13 & 3.32 \\
\hline Once a week & 22 & 5.63 \\
\hline Once in every two weeks & 9 & 2.30 \\
\hline Once in 3 weeks or more & 4 & 1.02 \\
\hline Total & $\mathbf{3 9 1}$ & $\mathbf{1 0 0 . 0 0}$ \\
\hline
\end{tabular}

Table 4 shows how often respondents use social network sites. Most participants (73.15\%) use social network sites daily. $14.58 \%$ use them once every $2-3$ days. Only $5.63 \%$ use it once a week and $1.02 \%$ access social media once in 3 weeks or more.

Table 5: Number of Hours Respondents Spend on Social Media Sites in a Day

\begin{tabular}{|l|l|l|}
\hline Social Network Site & Frequency & $\%$ \\
\hline Less than 1 hour & 190 & 48.90 \\
\hline Between 1-3 hour & 117 & 29.92 \\
\hline Between 3-5 hour & 45 & 11.51 \\
\hline Between 5-7 hour & 17 & 4.35 \\
\hline
\end{tabular}




\begin{tabular}{|l|l|l|}
\hline Between 7-9 hours & 7 & 1.79 \\
\hline More than 9 hours & 15 & 3.84 \\
\hline Total & $\mathbf{3 9 1}$ & $\mathbf{1 0 0 . 0 0}$ \\
\hline
\end{tabular}

Table 5 shows that most College of Education students (48.9\%) spend less than an hour a day on various social media platforms. Cost of internet data bundles and lack of access to effective Wi-Fi on the campuses of most Colleges of Education might account for the smaller number of hours that Pre-service Teachers spend on social media.

Again, to find out the Pre-service Teachers' perception of the usefulness of social media, the result is analysed in Table 6 using means.

The following are the decision rule for mean values, 1.0-1.5 very low; 1.6-2.4 low; 2.5-3.4 average; 3.5-4.4 high and 4.5 to 5.0 very high.

Table 6: Descriptive score of PU

\begin{tabular}{|l|l|l|l|l|}
\hline S/N & ITEM & Mean & Standard deviation & Decision \\
\hline 1 & $\begin{array}{l}\text { Social media makes me more productive in my social } \\
\text { relationships (social networking) }\end{array}$ & 4.20 & 0.04 & High \\
\hline 2 & $\begin{array}{l}\text { Social networking sites gives me quicker access to } \\
\text { news, and entertainment }\end{array}$ & 3.99 & 0.05 & High \\
\hline 3 & $\begin{array}{l}\text { Social networking sites are useful when I want to } \\
\text { contact my tutors }\end{array}$ & 4.19 & 0.05 & High \\
\hline 4 & $\begin{array}{l}\text { Social networking sites are useful when I want to } \\
\text { contact my colleagues }\end{array}$ & 3.99 & 0.04 & High \\
\hline 5 & Overall, I think social network sites are useful to me & 3.95 & 0.05 & High \\
\hline & Mean of means & $\mathbf{4 . 0 6}$ & $\mathbf{0 . 0 5}$ & High \\
\hline
\end{tabular}

From Table 6 , most Pre-service Teachers $(\mathrm{M}=4.2, \mathrm{STD}=0.04)$ strongly agreed that social media makes them productive in their social relationships. Majority of the Pre-service Teachers $(M=3.99, S T D=0.05)$ agreed that social media gave them quicker access to news and entertainment. Similarly, most of the Pre-service Teachers $(\mathrm{M}=4.19, \mathrm{STD}=0.05)$ agreed that they use social media when they want to connect with tutors. Likewise, many of the Pre-service Teachers (M $=3.99, \mathrm{STD}=0.05)$ use social media to contact their colleagues. In totality, most Pre-service Teachers $(\mathrm{M}=3.95, \mathrm{STD}=$ 0.05 ) find social media to be useful. The results indicate a total average mean of 4.06 .

To further find out Pre-service Teachers' perception of ease of use of social media, the mean scores are used to analyse the data and the result is shown in Table 7. The following are the decision rule for mean values, 1.0-1.5 very low; 1.6-2.4 low; $2.5-3.4$ average; $3.5-4.4$ high and 4.5 to 5.0 very high.

Table 7: Descriptive score of PEOU

\begin{tabular}{|l|l|l|l|l|}
\hline S/N & ITEM & Mean & Standard Deviation & Decision \\
\hline 1 & $\begin{array}{l}\text { I find social media easy to use because I have easy access } \\
\text { to internet }\end{array}$ & 4.11 & 0.04 & High \\
\hline 2 & $\begin{array}{l}\text { My interactions with social media apps are clear and } \\
\text { understandable. }\end{array}$ & 4.35 & 0.04 & High \\
\hline 3 & Learning how to use social media was easy for me & 3.78 & 0.05 & High \\
\hline 4 & $\begin{array}{l}\text { Social media is more convenient for me than other } \\
\text { communication systems such as email and text messages }\end{array}$ & 3.86 & 0.05 & High \\
\hline 5 & Overall, I find social media easy to use & 4.11 & 0.04 & High \\
\hline & Mean of means & 4.04 & 0.04 & High \\
\hline
\end{tabular}

From Table 7, most Pre-service Teachers $(\mathrm{M}=4.11, \mathrm{STD}=0.04)$ strongly agree that social media is easy to use because they have easy access to the internet. Similarly, most Pre-service Teachers $(\mathrm{M}=4.35, \mathrm{STD}=0.04)$ strongly agree that their interactions with social media apps are clear and understandable. Likewise, the majority of Pre-service Teachers 
$(\mathrm{M}=3.78,0.05)$ agree that learning how to use social media is easy.

Additionally, the majority of the Pre-service Teachers $(M=3.86, S T D=0.05)$ agreed that social media was more convenient to use as compared to email and text messages. In total, Pre-service Teachers $(M=4.11, S T D=0.04)$ agreed that social media was overall easy to use.

To answer the hypothesis, a t-test was conducted for the Equality of Variance and Means between Pre-service Teachers whose usage of social media sites were influenced by their perceived usefulness and those whose usage of social media sites were influenced by their perceived ease of use. The result is displayed in Table 8.

Table 8: T-Test for Equality of Variance and Means

\begin{tabular}{|l|l|l|l|l|l|}
\hline College of Education students' Social media site usage & $\mathbf{N}$ & $\mathbf{M}$ & $\mathbf{S D}$ & $\mathbf{T}$-value & P-value \\
\hline $\begin{array}{l}\text { College of Education students whose social media site usage } \\
\text { was influenced by their perceived usefulness }\end{array}$ & 391 & 4.06 & 0.05 & 0.440 & 0.037 \\
\hline $\begin{array}{l}\text { College of Education students whose social media site usage } \\
\text { was influenced by their perceived ease of use }\end{array}$ & 391 & 4.04 & 0.04 & & \\
\hline
\end{tabular}

Table 8 shows the test for equality of means between Pre-service Teachers whose social media site usage was influenced by their perceived usefulness and those whose social media site usage was influenced by their perceived ease of use. Since the equality of variance assumption is validated the researchers used the first 2-tailed significant value of a test for equality of means at a p-value of 0.037 which is less than a significant level of 0.050 . The researchers, therefore, have enough evidence to reject the null hypothesis.

In other words, we reject $\mathrm{H}_{0}$ at the $5 \%$ significance level and conclude that there is a significant difference between Pre-service Teachers whose social media site usage was influenced by their perceived usefulness and those whose social media site usage was influenced by their perceived ease of use.

Lastly, Eta square value was computed to determine, the proportion of variances of the dependent variable explained by the independent variable. The value of the Eta Square (0.045) shows the proportion of the variance in the use of social media sites by Pre-service Teachers whose social media site usage were influenced by their perceived usefulness and those whose social media site usage was influenced by their perceived ease of use. The Eta square is moderate, $\mathrm{t}(391)=0.440, \mathrm{p}=0.037$ (two-tailed), $\mathrm{d}=0.050$, indicating that there is a significant difference between Preservice Teachers whose social media site usage was influenced by their perceived usefulness and those whose usage was influenced by their perceived ease of use but the difference was not much.

\section{DISCUSSIONS}

The result of this study indicates that the majority of college students use social media (Facebook (84.40\%), WhatsApp (96.16) and YouTube (57.29\%)). This result affirms results from Aaron and Monica that indicated that young people have historically been the most prolific users of social networks by a significant margin. ${ }^{28}$ Again data from the results show that the majority of the students use more than one social media platform. The most popular social media site students visit are WhatsApp and Facebook. This is in line with Korsah et al whose research found that WhatsApp and Facebook are the most used social media services by students of Komenda College of Education. ${ }^{29}$ Similarly, in their article on the effect of WhatsApp Messenger Use on Student Performance in Tertiary Institutions in Ghana, Yeboah \& Ewur results indicated that WhatsApp is the key social media service used by students to chat. Students also use social media daily. ${ }^{30}$ The majority of the respondents (51.1\%) spend more than 1 hour on social media. This corroborates a similar study, which noted that an internet user spends a little over two hours socializing online, mostly occurring on the world's six major social media platforms (WhatsApp, Facebook, Twitter, Instagram, YouTube and Snapchat). ${ }^{31}$

The results of the objective that sought to find out the Pre-service Teachers' perception of the usefulness of social media suggests a total average mean of 4.06. This interpretation shows that the Perceived Usefulness (PU) of social media is high among Pre-service Teachers in Ghana. This finding agrees with many studies that indicate students have a

\footnotetext{
28 aron Smith \& Monica Anderson, “Social Media Use in 2018," Accessed March 1, 2018 https://www.pewresearch.org/internet/2018/03/01/social-media-usein-2018/.

29 Daniel P. Korsah, Justice Enu, Waziru Ibrahim, “Students' engagement with social media: A case study at Komenda College of education," International Journal of Multidisciplinary Research and Development, 4, No. 6 (2017): 344 - 350

30 Johnson Yeboah \& George D. Ewur, “The Impact of Whatsapp Messenger Usage on Students Performance in Tertiary Institutions in Ghana," Journal of Education and Practice 5(2014):157-164

31 S. Aleksandar, "How Much Time Do People Spend on Social Media in 2019?" (Blog) October 21, 2019, https://www.techjury.net/blog/ time-spent-on-socialmedia/.
} 
high perception of the usefulness of social media. ${ }^{32}$

The result of Pre-service Teachers' perception of ease of use of social media suggests a total average mean of 4.04.This indicates that the Perceived Ease of Use (PEOU) of social media is high among Pre-service Teachers in Ghana. Several other studies have shown that students can easily use social media. ${ }^{33}$

The t-test score of the Equality of Variance and Means between Pre-service Teachers whose usage of social media sites were influenced by their perceived usefulness and those whose usage of social media sites were influenced by their perceived ease of use, shows that there is a significant difference between Pre-service Teachers whose social media site usage was influenced by their perceived usefulness and those whose usage was influenced by their perceived ease of use.

This study has revealed that Pre-service Teachers make use of social media platforms with WhatsApp and Facebook recording the highest usage. Pre-service Teachers find social media useful, as they perceive benefits such as Perceived Enjoyment, Computer Self-Efficacy and Job Relevance in terms of getting relevant information on their profession as teachers through social media platforms. Again, social media makes Pre-service Teachers productive in their social relationships and gives them quicker access to news and entertainment. Additionally, social media allow the students to connect with tutors and their colleagues. The study further reveals that Pre-service Teachers find social media convenient to use due to varied reasons such as less complexity and ability to access them on smart phones.

\section{RECOMMENDATIONS}

Based on the findings made, the researchers recommend that the Governing Councils of the various Colleges of Education should make the provision of internet facilities in the various Colleges of Education a priority. The provision of the internet services will not only enhance social media and the use of e-learning applications but will also enhance research and communication among students and tutors of Colleges of Education. In addition, the Governing Councils of Colleges of Education should also encourage social media-friendly policies that foster its incorporation into teaching and learning since most students are on that channel. Again, teachers should be encouraged to integrate e-learning technologies like Blackboard, Google Classroom and Edmodo, in their teaching courses since they have social medialike features that students have already embraced.

\section{CONCLUSION}

The outcome of the study established the fact that a significant difference exists between Pre-service Teachers whose usage of social media sites specifically affect their perceived usefulness and those whose usage - specifically affect their perceived ease of use. Again, there is a high perception of perceive usefulness and ease of use of social media among preservice teachers in Ghana. The study further affirms that most pre-service teachers use social media platforms especially WhatsApp and Facebook.

\section{BIBLIOGRAPHY}

Agichtein Eugene, Castillo Carlos, Donato Debora, Gionis Aristides, and Mishne Gilad, "Finding high-quality content in social media," In WSDM '08: Proceedings of the international conference on Web search and web data mining, (2008):183-194.

Aleksandar, S. "How Much Time Do People Spend on Social Media in 2019?” (Blog) October 21, 2019, https://techjury. net/blog/time-spent-on-social-media/.

Al-Ghaith Waleed., "Applying the Technology Acceptance Model to Understand Social Networking Sites (SNS) Usage: Impact of Perceived Social Capital," International Journal of Computer Science and Information Technology, 7, no. 4 (2015): 105-117.

Auvinen Ari-Matti, n.d., "Social Media - The New Power of Political Influence," Accessed August 4" 2016 http://www. martenscentre.eu/sites/default/files/publication-files/social-media-and-politics-power-political-influence. pdf

Chan Tze Leong, "Cronbach's alpha below 0.7," Accessed February 19 ${ }^{\text {th }}, 2013$. https://www.researchgate.net/post/ Cronbachs_alpha_below_07

Chen, L., Gillenson, L. M., \& Sherrell, L. D., "Consumer acceptance of virtual stores: a theoretical model and critical success factors for virtual stores," ACM SIGMIS Database, 35, no. 2 (2004): 8-31.

\footnotetext{
32 Pratisha Padmasri Deka, "A Study on Impact of Social Media on Educational Efforts in Guwahati City, Assam," International Journal of Advanced Research in Education Technology 2, no. 3 (2015):90-94.

33 Roma Subramanian, Kevin Wise, Doug Davis, Manu Bhandari , and Erin Morris , "The relative contributions of implicit and explicit self-esteem to narcissistic use of Facebook," Computers in Human Behavior 39, No. 1, (2014):306-311.
} 
Chin Wynne, W., Norman Johnson, and Schwarz Andrew, "A Fast Form Approach to Measuring Technology Acceptance and Other Constructs," MIS Quarterly 32, no. 4 (2008): 687-703. Accessed June 27, 2020. doi:10.2307/25148867.

Degadjor Mac-Jordan D., "Social Media and Internet Use in Ghana," 2010, Accessed March 1', 2017. https://www. slideshare.net/macjordangh/social-media-internet-use-in-ghana

Deka Pratisha Padmasri, "A Study on Impact of Social Media on Educational Efforts in Guwahati City, Assam," International Journal of Advanced Research in Education Technology, 2, no. 3 (2015):90-94.

Djamasbi Soussan, Strong Diane M., \& Dishaw Mark "Affect and acceptance: Examining the effects of positive mood on the technology acceptance model," Decision Support Systems, 48, (2010):383-394.

Draskovic, Nikola, Caic, Martina., \& Kustrak, Ana, "Croatian perspective(s) on the lecturer student interaction through social media," International Journal of Management Cases, 15, no. 4, (2013):331-339.

Durodolu Oluwole, "Technology Acceptance Model as a predictor of using information system" to acquire information literacy skills," Library Philosophy and Practice, (2016):1450.

Friedman Thomas L., "The World Is Flat 3.0: A Brief History of the Twenty-first Century," Picador (2007).

Kaplan Andreas M., \& Michael Heinlein, "Users of the world, unite! The challenges and opportunities of social media," Business Horizons 53, no. 1 (2010): 59-68. , "Users of the world, unite! The challenges and opportunities of social media," Business Horizons 53, no. 1 (2010): 59-68.

Kietzmann Jan H. , Hermken Kristopher, McCarthy Ian P. \& Silvestre Bruno S., "Social media? Get serious! Understanding the functional building blocks of social media," Business Horizons 54, 3(2011): 241-251.

Kop Rita \& Hill Adrian, "Connectivism: Learning theory of the future or vestige of the past?" International Review of Research in Open and Distance Learning, 9, no 3 (2008): 1-13.

Korsah Daniel Paa, Enu Justice, Ibrahim Alhaji Waziru, "Students' engagement with social media: A case study at Komenda College of Education," International Journal of Multidisciplinary Research and Development, 4, No. 6 (2017): $344-350$.

Kurniabudi Kurniabudi, Sharipuddin \& Assegaff Setiawan, "A Literature Review: Acceptance Models or e-learning Implementation in Higher Institution," International Conference on Advances in Education Technology (ICAET-14), (2015):86-89.

McCoy, S., Galletta, D. \& King, W., "Applying TAM across cultures: the need for caution," European Journal of Information Systems 16 (2007): 81-90.

Ogbonnaya, U.I. \& Mji, A., "Pre-Service Teachers' Use Of Social Media," Edulearn 15 Proceedings, (2015):1506-1512.

O’Reilly Tim, "What Is Web 2.0: Design Patterns and Business Models for the Next Generation of Software," September 30, 2005, Accessed January 6, 2019 http://www.oreilly.com/pub/a/web2/archive/what-is-web-20.html.

Smith Aaron \& Anderson Monica, "Social Media Use in 2018," Accessed March 1', 2018. https://www.pewresearch.org/ internet/2018/03/01/social-media-use-in-2018/.

Subramanian Roma, Wise Kevin, Davis Doug, Bhandari Manu, and Morris Erin, "The relative contributions of implicit and explicit self-esteem to narcissistic use of Facebook," Computers in Human Behavior 39, No. 1, (2014):306311.

Tay Elaine, \& Allen, Matthew, "Designing social media into university learning: technology of collaboration or collaboration for technology?” Educational Media International, 48, no3, (2011):151-163. doi:10.1080/0952 3987.2011.607319

Teclehaimanot, Berhane \&Torey Hickman, "Student-Teacher Interaction on Facebook: What Students Find Appropriate," TechTrends 55 (2011): 19-30.

Tuurosong Damasus \& Amadu Mohammed, (2014). “The Social Media Scourge among University Students: A Study of the University for Development Studies, Ghana”. J. Asian Dev. Stud, 3, no 2, (2014): 62-74.

Venkatesh Viswanath, "Determinants of Perceived Ease of Use: Integrating Control, Intrinsic Motivation, and Emotion into the Technology Acceptance Model," Information Systems Research 11, no. 4(2000): 342-365.

Warrens Matthijs J., "On Cronbach's Alpha as the Mean of All Possible k-Split Alphas," Advances in Statistics, (2014).

Wilson Davis W., Lin Xiaolin, Longstreet Pjil, \& Sarker Saonee, "Web 2.0: A definition, literature review, and directions for future research," AMCIS 2011 Proceedings of the Seventeenth Americas Conference on Information systems, Detroit, Michigan August 4-7 2011.

Yeboah Johnson \& Ewur George Dominic, "The Impact of Whatsapp Messenger Usage on Students Performance in Tertiary Institutions in Ghana," Journal of Education and Practice 5(2014):157-164. 


\section{ABOUT AUTHORS}

Daniel Paa Korsah is an ICT tutor at the Department of Mathematics and ICT, Komenda College of Education. He holds a Bachelor of Education in Computer Science and a Master of Education (Information Technology) from the University of Cape Coast, Ghana. Email: danielpaakorsah@gmail.com

Issah Bala Abdulai is a tutor in the Department of Mathematics and ICT at the Kibi Presbyterian College of Education. He holds a Master of Science (IT) from Sikkim Manipal University, India - Ghana campus and a Master of Education (Information Technology) from University of Cape Coast, Ghana. Email: isa_bala@yahoo.com

Daniel Gbormittah is a Mathematics tutor at the Department of Mathematics and ICT Education, Komenda College of Education. He holds both Bachelor of Education in Mathematics and Master of Philosophy in Mathematics Education from the University of Cape Coast, Ghana. Email:gbormittahdaniel@gmail.com 